Original article

\title{
Burden of illness of dog-mediated rabies in India: A systematic review
}

\author{
Denny John ${ }^{\mathrm{a}}$, Abhishek Royal ${ }^{\mathrm{b}, *}$, Omesh Bharti ${ }^{\mathrm{c}}$

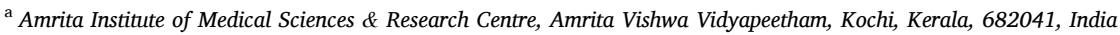 \\ ${ }^{\mathrm{b}}$ Faculty of Medicine, Public Health and Nursing, Universitas Gadjah Mada, Yogyakarta, 55281, Indonesia \\ ${ }^{\mathrm{c}}$ State Institute of Health and Family Welfare, Department of Health \& Family Welfare, Government of Himachal Pradesh, Shimla, 171009, India
}

\section{A R T I C L E I N F O}

\section{Keywords:}

Burden of illness

Cost

Dog bite

India

Rabies

\begin{abstract}
A B S T R A C T
Introduction: India accounts for $35 \%$ of global burden of rabies. This systematic review attempts to measure the burden of illness of dog bites and dog-mediated rabies in India.

Methods: A systematic literature search was conducted on MEDLINE, EMBASE, Cochrane Central, PROQUEST, Sodhganga and Google Scholar. Two independent reviewers screened titles and abstracts and included full texts as per inclusion criteria. Critical appraisal of included studies was conducted using appropriate checklists. Data was extracted using standardized data extraction tools, analyzed and reported in narrative summary and tabular formats.

Results: 35 studies were included for narrative synthesis after screening for inclusion criteria. The annual crude dog bite incidence was reported between $0.26 \%$ and $2.5 \%$ with stray dogs as main biting animal. The bites were mainly reported in males, between age group 10-40 years, individuals belonging to low socio-economic status and people working in fields. The annual economic and humanistic burden is estimated to be 2.85 million USD and 1.3 million DALYs respectively. Use of intradermal route of vaccination and equine rabies immunoglobulins has been reported to save cost and resources over use of intramuscular route of vaccination and human rabies immunoglobulins.

Conclusion: The review highlighted the burden of disease at local, regional and national level. There has been dearth of studies reporting economic and humanistic burden at national level.

Systematic review registration: PROSPERO ID: CRD42020213261.
\end{abstract}

\section{Introduction}

Rabies is a viral zoonotic disease which results in 59,000 (95\% CI: $25-159,000$ ) deaths and is responsible for economic loss of 8.6 billion USD (95\% CI: $2.9-21.5$ billion) and 3.7 million (95\% CI: $1.6-10.4$ million) disability-adjusted life years (DALYs) across the globe annually. ${ }^{1}$ The disease is almost fatal after the onset of clinical symptoms and results in painful deaths due to acute progressive encephalitis. Most of the cases occur in underserved population in Africa and Asia with approximately $40 \%$ of cases in children below 15 years of age. ${ }^{2}$ More than $95 \%$ of human cases across the globe are caused due to dog bites. ${ }^{3}$

Rabies is an endemic disease in India. It is prevalent in all the states and union territories of the country except Andaman \& Nicobar and Lakshadweep Islands. Hampson K. et al. (2015) estimated that India accounts for $35 \%$ of the global burden of rabies. ${ }^{1}$ Another study conducted in 2010 through probability decision tree approach by Partners for Rabies Prevention (PRP) estimated 16,450 (95\% CI: 6000-27,000) rabies deaths in the country. ${ }^{3}$ An enhanced verbal autopsy survey within Million Death Study (MDS) projected 12,700 (99\% CI: 10,000-15,500) symptomatically identifiable rabies deaths in India in 2005 and further reported that $91 \%$ of these deaths occur in rural areas, $62 \%$ in males, and $50 \%$ in children below 15 years of age. ${ }^{4}$ The overall mortality was estimated to be 1.1 (99\% CI: 0.9-1.4) deaths per 1,00,000 population with one-third of these deaths in the state of Uttar Pradesh and three-fourth in 7 central and south-eastern states. ${ }^{4}$

WHO categorizes risk exposure for animal bites in to category I (no exposure), category II (exposure) and category III (severe exposure). The disease can be prevented by timely administration of post-exposure prophylaxis (PEP) to the bite victims. This includes wound management as per recommendations and; administration of rabies vaccines through intramuscular (IM) or intradermal (ID) routes under different schedules in category II and III exposures and rabies immunoglobulins in previously non-vaccinated category III exposures. ${ }^{2,3,5}$

In India, the annual incidence of animal bites is estimated to be $1.7 \%$

\footnotetext{
* Corresponding author. 1520, Khirni, Hathras, Uttar Pradesh, 204101, India.

E-mail addresses: djohn1976@gmail.com (D. John), abhishekroyal2010@gmail.com (A. Royal), bhartiomesh@yahoo.com (O. Bharti).
} 
(17.5 million per year). ${ }^{6}$ The Integrated Disease Surveillance Programme (IDSP) reported an increase in animal bites from 4.2 million in 2012 to 7.4 millions in 2018 with dogs. ${ }^{7}$ The World Health Organisation (WHO), World Organization for Animal Health (OIE), Food and Agriculture Organization of the United Nations (FAO) and the Global Alliance for Rabies Control (GARC) has set a goal of zero dog-mediated rabies deaths by 2030 and joined forces as the United Against Rabies collaboration. $^{8}$ The WHO through its Strategic Advisory Group of Experts (SAGE) has recognized the importance of the programmatic experiences and evidences on rabies control from India towards achieving this goal as India contributes to one-third of the global rabies deaths. ${ }^{8}$ Generation of evidence-based guidance and high-quality data to measure impact and inform policy decisions has been coined as an important objective under this Global Strategic Plan 'to end human deaths from dog-mediated rabies by 2030 , 8

The incidence of rabies has remained stagnant and grossly underreported in India since a decade. ${ }^{9}$ There is serious need to improve reporting systems to address the issue of lack of accurate data and its verification in a number of regions in the country as the true burden of the disease is not reflected in the hospital data. ${ }^{10}$ This systematic review on burden of illness attempts to measure the magnitude of the epidemiological, humanistic and economic burden of dog bites and dog-mediated rabies in India.

\section{Materials and methods}

The systematic review has been conducted and reported in accordance with the guidelines from the Preferred Reporting Items for Systematic Review and Meta-Analyses (PRISMA). ${ }^{11}$ The protocol of this Systematic Review has been registered with the International Prospective Register of Systematic Reviews (PROSPERO ID: CRD42020213261) and a detailed protocol has already been published. ${ }^{12}$

\subsection{Literature search}

A systematic literature search was conducted on MEDLINE, EMBASE, Cochrane Central, PROQUEST, Sodhganga and Google Scholar to identify all published studies reporting epidemiological, humanistic and economic burden of dog bites and dog-mediated rabies in the context of India. The studies not reporting data on the outcomes of interest such as rabies due to animals other than dogs, in languages other than English and conducted on non-human subjects were excluded. The studies reporting unit/per-capita costs were included irrespective of the differentiation of the animal and dog bites following the assumption that there is no difference in the regimens and thereby per unit costs of the prophylaxis. However, the total costs were not extracted from these studies. Further, the web-portals of Integrated Disease Surveillance Programme (IDSP), Health Management Information System (HMIS) and Central Bureau of Health Intelligence (CBHI) were explored for any administrative data. An advisory board comprising of experts and researchers was established to identify grey literature and technical reports. The search strategy is provided in the supplementary file 1.

\subsection{Study selection}

All the identified studies were initially pooled and uploaded in Rayyan QCRI software and duplicates were later removed. ${ }^{13}$ Titles and abstracts were screened against the inclusion criteria by two independent reviewers. The eligible studies were retrieved in full-text and assessed by these two reviewers. Any disagreement at any stage of selection process was resolved through discussion or in consultation with a third reviewer.

\subsection{Data extraction}

Data from the included studies were extracted to pre-designed templates in MS Excel 2007. The results are described in tabular formats and a narrative summary is presented in this article. The costs are converted in 2020 International Dollars' value using implicit price deflators for Purchasing Power Parities as recommended by Campbell \& Cochrane Economic Methods Group (CCEMG) for comparability across studies. $^{14}$

\subsection{Quality assessment}

The included studies were assessed for their methodological quality using various checklists including STROBE checklist for cohort and cross-sectional studies, Consolidated Health Economics Evaluation Reporting Standards (CHEERS) checklist for full economic evaluations, Consensus Health Economic Criteria (CHEC) list for partial economic evaluations, and Optional scoring checklist for the assessment of the degree of model validation for modeling studies. ${ }^{15-19}$

\section{Results}

\subsection{Search and screening}

A total of 1474 studies were identified through literature search. 482 duplicates were removed and 992 articles were subjected for electronic screening. Only 66 studies were included after reviewing their titles and abstracts for inclusion criteria. A total number of 83 studies were included for full text screening after including 17 additional studies as suggested by the advisory board. 35 studies were finally included for data extraction after full text screening. The reasons for exclusion of studies are mentioned in PRISMA 2020 Flow Diagram (Fig. 1). Out of these 35 included studies, 25 reported epidemiological outcomes only: 19 cross-sectional studies, ${ }^{4,20-39} 3$ cohort studies (2 prospective cohort $^{40,41}$ and 1 retrospective cohort studies ${ }^{42}$ ) and 1 modeling study. ${ }^{43}$ Nine studies reported economic outcomes only ${ }^{44-52}$ and all of these studies were partial economic evaluation (2 prospective cohort studies, ${ }^{51,52} 6$ cross-sectional studies ${ }^{44-46,48-50}$ and 1 on implementation cost of interventions ${ }^{47}$ ). Only one modeling study reported all the three outcomes: epidemiological, economic and humanistic. ${ }^{1}$

Out of 35 included studies, 23 were hospital (or clinic) based, ${ }^{20-22,24-31,38,41,42,44-52} 9$ were community (or household) based $^{4,23,32-35,37,39,40}$ and 2 were modeling studies at country level ${ }^{1,43}$ and 1 was laboratory-based study. ${ }^{36}$

\subsection{Quality assessment}

The cohort studies included for epidemiological outcomes failed to describe any efforts to address potential sources of bias, statistical methods, other analyses undertaken and their external validity. ${ }^{40-42}$ The criteria that were not reported in cross-sectional studies included for epidemiological outcomes were bias (95.2\%), ${ }^{4,21-39}$ other analyses $(76.2 \%),{ }^{20-30,32,35-38}$ generalisability $(71.4 \%),{ }^{20-24,26-28,30-32,34-36,38}$ limitations (61.9\%), ${ }^{21-24,26-31,34-36,39}$ Data Source/measurement $(61.9 \%),{ }^{21-30,32,35,36,38,39}$ quantitative variables $(57.1 \%)^{21}$, $22,24,26-28,32,33,35,36,38,39$ and funding $(52.4 \%) .^{20-23,27-30,32,34,36}$

None of the study reporting economic outcomes only (partial economic evaluation) has reported incremental analysis of costs and outcomes. Only $11.1 \%$ of the studies reported discount rates, ${ }^{47}$ sensitivity analysis ${ }^{47}$ and generalisability of the results ${ }^{51}$ while $22.2 \%$ of the studies reported outcomes for each identified alternative and had measured and valued all outcomes appropriately. ${ }^{51,52} 33.3 \%$ of the studies discussed ethical and distributional issues. ${ }^{45,46,51}$

The decision tree model failed to mention the incremental costs and outcomes and the title of the paper do not mention it as economic evaluation or cost-effectiveness study. ${ }^{1}$ Moreover, it was scored 30 out of 34 for its quality of modeling. ${ }^{1}$ The simulation model was scored 19 out of 34 after its critical appraisal. ${ }^{43}$

The detailed critical appraisal of all the studies is provided in 


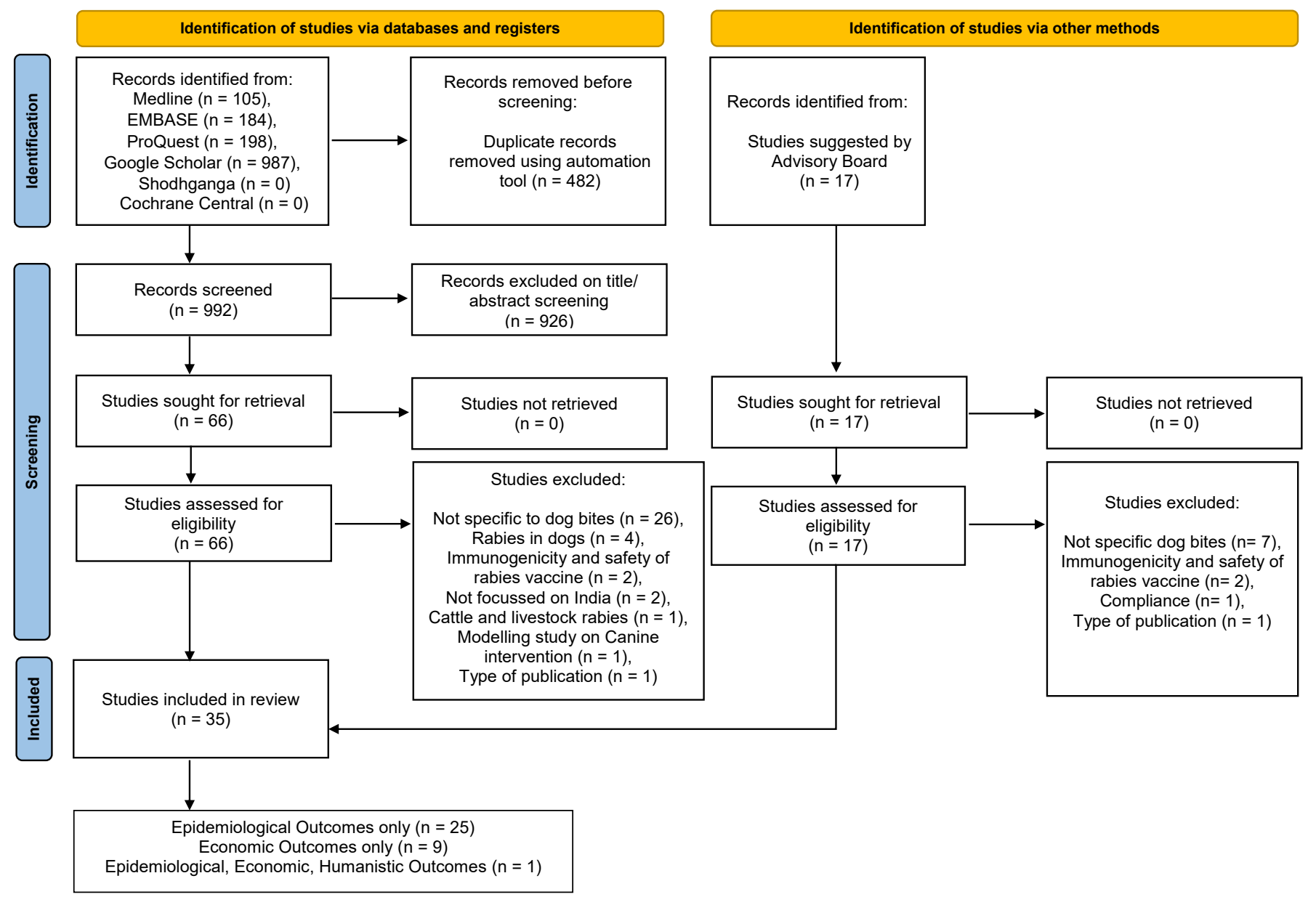

Fig. 1. Flow of literature (PRISMA 2020 Flow Diagram).

Supplementary file 2 .

\section{Burden of dog-bites and dog mediated rabies}

\subsection{Epidemiological burden}

The study participants of the reporting studies were animal bite victims (9 studies), ${ }^{20-26,40,41}$ dog bite victims (7 studies), ${ }^{27-31,38,42}$ general population (5 studies), ${ }^{32-35}$ clinically rabies suspected cases (1 study), ${ }^{36}$ households of rabies cases ( 1 study) ${ }^{37}$ and national representative survey of deaths ( 1 study). ${ }^{4}$ The models included were based on decision tree and simulation method. ${ }^{1,43}$ One study in the dog bitten participants were conducted on children below 15 years of age respectively. ${ }^{27}$ The studies conducted on the general population were community-based. ${ }^{32-35}$ One of the community based study was conducted on children $\leq 16$ years of age. Only the data reported on dog bites is included from studies conducted on animal bite victims. A detailed description of the included studies, socio-demographics of bite victims and description of the bites is mentioned in Tables $1-3$ respectively.

\subsubsection{Prevalence/incidence of dog-bites}

A retrospective study conducted on the surveillance data in 2012 reported 938 dog bites in one year in Union Territory of Dadar and Nagar Haveli. The crude incidence rate of dog bites was reported to be 26.05 per 10,000 people in this study. ${ }^{42}$ Another prospective cohort study conducted on 1080 household population in rural areas in Bangalore reported an incidence of 27 animal bites in one year (2010-11) where all the biting animals were dogs and the annual incidence of animal bite was $2.5 \%{ }^{40}$ A cross sectional study conducted in slums of North-West Delhi reported a dog bite rate of 25.2 per 1000 (95\%CI: 20.2-31.7/1000) persons from January 2014-August 20, $14 .^{33}$ The dog bite rate in this study was lower in rural slum $(19.6 / 1000,95 \%$ CI: 14.2-29.4/1000) than urban slum (30.1 per 1000, 95\%CI: $22.5-40.6 / 1000)$ but the findings were not statistically significant $(\mathrm{P}=$ 0.09). Two community based cross-sectional studies conducted on animal bites in rural settings of Tamil Nadu (2013-14) and Punjab (2020) reported a period prevalence of $22.3 / 1000$ and bite incidence of $68 / 1000$ population respectively and mentioned dog bites as the most common form of animal bites. ${ }^{23,35}$ The annual dog bite incidence was reported to be $3.36 \%$ in children $\leq 16$ years of age in a study conducted in rural parts of Goa in 2018. A study based on dog-bite probability model published in 2005 estimated the number of bites from rabid dogs in rural and urban India to be around 893,400 and 409,400 respectively. ${ }^{43}$ Another modeling study published in 2015 reported 4,581,603 (95\% CI: 1,553,000-9,619,000) annual canine (dog) bite exposures in the country. ${ }^{1}$

\subsubsection{Socio-demographics of dog-bite victims}

Age: The cross-sectional study on dog bitten children below 15 years of age reported $61.4 \%$ of total cases in the age group of 7-12 years. ${ }^{27}$ Furthermore, four studies mentioned that bite victims in the age group of $0-10$ years were $11.7 \%, 34.1 \%, 11.3 \%$ and $22.4 \%$ of the total victims respectively. ${ }^{29,31,34,42}$ These studies also reported that maximum number of the bites were in the age group of $10-40$ years: $56.25 \%, 68.8 \%$, $61.32 \%$ and $46.27 \%$ respectively. The victims above the age of 60 years were reported to be $8.2 \%, 4.4 \%, 6.38 \%$ and $4.4 \%$, of the total victims in 
Table 1

Characteristics of studies included in the review for Epidemiological Outcome.

\begin{tabular}{|c|c|c|c|c|c|c|c|c|}
\hline Study & Study Design & Location & Study period & Setting & Participants & $\begin{array}{l}\text { Number of Participants } \\
\text { of the study }(\mathrm{N})\end{array}$ & $\begin{array}{l}\text { Number of Dog bite } \\
\text { victims/Dog mediated } \\
\text { rabies (n) }\end{array}$ & $\begin{array}{l}\text { Study } \\
\text { Quality }\end{array}$ \\
\hline $\begin{array}{l}\text { Agarwal N } \\
2004^{32}\end{array}$ & Cross sectional & Ballabgarh, Haryana & January 2002 & $\begin{array}{l}\text { Community based } \\
\text { (Rural) }\end{array}$ & General Population & 970 & 25 & Low $^{\mathrm{a}}$ \\
\hline $\begin{array}{l}\text { Knobel, } \\
\text { Darryn L } \\
2005^{43}\end{array}$ & $\begin{array}{l}\text { Modeling Study (Simulation } \\
\text { Method) }\end{array}$ & Asia and Africa (India) & 2005 & $\begin{array}{l}\text { Country level } \\
\text { estimation }\end{array}$ & $\begin{array}{l}\text { Based on data on dog } \\
\text { (canine) bite victims }\end{array}$ & NA & $\begin{array}{l}\text { Rabies deaths }=19, \\
713[4192-39733]^{\#}\end{array}$ & $19 / 34^{\mathrm{b}}$ \\
\hline $\begin{array}{l}\text { M.K. } \\
\text { Sudarshan } \\
2007^{37}\end{array}$ & Cross-sectional & $\begin{array}{l}\text { National Representative } \\
\text { Multicentric Survey }\end{array}$ & February-August 2003 & Community based & $\begin{array}{l}\text { General Population } \\
\text { (Household of the rabies } \\
\text { case) }\end{array}$ & 235 & Rabies Deaths $=226$ & $\operatorname{High}^{\mathrm{a}}$ \\
\hline $\begin{array}{r}\text { Teena M } \\
2012^{20}\end{array}$ & Cross sectional & $\begin{array}{l}\text { Thiruvananthapuram, } \\
\text { Kerala }\end{array}$ & April-August 2010 & Hospital based & Animal bite victims & 320 & 225 & $\operatorname{High}^{\mathrm{a}}$ \\
\hline $\begin{array}{l}\text { Hemagiri K } \\
2012^{27}\end{array}$ & Cross sectional & Bellary, Karnataka & February-November 2011 & Hospital based & $\begin{array}{l}\text { Dog bitten Children }<15 \\
\text { years }\end{array}$ & 536 & 536 & Low ${ }^{\mathrm{a}}$ \\
\hline Shah V $2012^{21}$ & Cross sectional & Ahemdabad, Gujarat & August-October 2010 & Hospital based & Animal bite victims & $\begin{array}{l}1112 \text { (Only } 3 \text { were cattle } \\
\text { bite victims) }\end{array}$ & 1109 & Low $^{\mathrm{a}}$ \\
\hline $\begin{array}{l}\text { Suraweera } \\
2012^{4}\end{array}$ & $\begin{array}{l}\text { Cross sectional; Verbal } \\
\text { Autopsy of deaths in Million } \\
\text { Death Study }\end{array}$ & $\begin{array}{l}\text { National Representative } \\
\text { Survey }\end{array}$ & $\begin{array}{l}2001-2003 \text { with projection for } \\
2005\end{array}$ & $\begin{array}{l}\text { Household, } \\
\text { community based } \\
\text { setting }\end{array}$ & $\begin{array}{l}\text { National Representative } \\
\text { Survey of } 122,000 \text { deaths }\end{array}$ & $\begin{array}{l}140 \text { (Total number of } \\
\text { rabies cases) }\end{array}$ & 136 & $\operatorname{High}^{\mathrm{a}}$ \\
\hline $\begin{array}{l}\text { V. Wankhede } \\
2013^{28}\end{array}$ & Cross sectional & Raigad, Maharashtra & $\begin{array}{l}\text { 1st September - } 30 \text { November } \\
2012\end{array}$ & $\begin{array}{l}\text { Hospital based } \\
\text { (Rural) }\end{array}$ & Dog bite victims & 318 & 318 & Low $^{\mathrm{a}}$ \\
\hline $\begin{array}{l}\text { Pratibha } \\
\text { Chauhan } \\
2013^{22}\end{array}$ & Cross sectional & Jodhpur, Rajasthan & $\begin{array}{l}\text { 1st January - 31st December } \\
2010\end{array}$ & Hospital based & Animal bite victims & $\begin{array}{l}4248 \text { (186 other animal } \\
\text { bites) }\end{array}$ & 4062 & Low $^{\mathrm{a}}$ \\
\hline $\begin{array}{l}\text { Ayan Ghosh } \\
2014^{34}\end{array}$ & Cross-sectional & Kolkata & 15th May - 15th June 2013 & Community based & General Population & 871 & 67 & Medium $^{a}$ \\
\hline $\begin{array}{l}\text { Venkatesan M } \\
2014^{23}\end{array}$ & Cross-sectional & $\begin{array}{l}\text { Thiruvenainallur, Tamil } \\
\text { Nadu }\end{array}$ & $\begin{array}{l}\text { 2013-2014 (published in } \\
\text { October-December 2014; } \\
\text { therefore assumption) }\end{array}$ & $\begin{array}{l}\text { Community based } \\
\text { (Rural) }\end{array}$ & Animal bite victims & $\begin{array}{l}\text { Total participants }= \\
\text { 12947; Animal bites and } \\
\text { evenomation }=1060\end{array}$ & 289 & Medium $^{\mathrm{a}}$ \\
\hline $\begin{array}{l}\text { V. Khan } \\
2014^{42}\end{array}$ & $\begin{array}{l}\text { Retrospective Cohort (2012) } \\
\text { based on Surveillance Data } \\
\text { (IDSP) }\end{array}$ & $\begin{array}{l}\text { Union territory of Dadra \& } \\
\text { Nagar Haveli }\end{array}$ & 2012 (1 year) & Hospital based & Dog bite victims & 938 & 938 & Medium $^{a}$ \\
\hline $\begin{array}{l}\text { Hampson } \\
\mathrm{K}^{2} 015^{1}\end{array}$ & $\begin{array}{l}\text { Modeling study (Probability } \\
\text { decision tree framework) }\end{array}$ & Global and country level & 2015 & $\begin{array}{l}\text { Country level } \\
\text { estimation }\end{array}$ & $\begin{array}{l}\text { Based on data on dog } \\
\text { (canine) bite victims }\end{array}$ & NA & $\begin{array}{l}20,847[95 \% \mathrm{CI}: \\
7000-55,000]\end{array}$ & $30 / 34^{\mathrm{b}}$ \\
\hline $\begin{array}{l}\text { Ramesh } \\
\text { Masthi } \\
2015^{40}\end{array}$ & Prospective Cohort & Bangalore & 2010-2011 (one year) & $\begin{array}{l}\text { Community based } \\
\text { (Rural) }\end{array}$ & $\begin{array}{l}\text { Animal bite victims (All } \\
\text { were dog bites) }\end{array}$ & 1080 (Cohort) & 27 & Medium $^{\mathrm{a}}$ \\
\hline $\begin{array}{r}\text { Sharma S } \\
2016^{33}\end{array}$ & Cross sectional & North-west Delhi & January-August 2014 & $\begin{array}{l}\text { Community based } \\
\text { (one urban and one } \\
\text { rural slum) }\end{array}$ & General Population & $\begin{array}{l}2887 \text { (1427:Rural; } \\
\text { 1460: Urban) }\end{array}$ & 183 & $\mathrm{High}^{\mathrm{a}}$ \\
\hline $\begin{array}{l}\text { Acharya R } \\
2016^{24}\end{array}$ & Cross sectional & Bikaner, Rajasthan & April 2012-March 2015 & Hospital based & Animal Bite Victims & 10916 & 10287 & Medium $^{a}$ \\
\hline $\begin{array}{l}\text { Marathe N } \\
2016^{25}\end{array}$ & Cross sectional & Rewa, Madhya Pradesh & February 2014-February 2015 & Hospital based & Animal Bite Victims & 406 & 389 & $\operatorname{High}^{\mathrm{a}}$ \\
\hline $\begin{array}{l}\text { R. S. Mani } \\
2016^{36}\end{array}$ & $\begin{array}{l}\text { Retrospective Analysis of } \\
\text { Data and Specimens }\end{array}$ & 11 states \& UT* & January 2012-December 2014 & $\begin{array}{l}\text { Laboratory based } \\
\text { surveillance }\end{array}$ & $\begin{array}{l}\text { All clinically suspected } \\
\text { cases of human Rabies }\end{array}$ & 128 & 19 (Rabies cases) & Low $^{\text {a }}$ \\
\hline $\begin{array}{l}\text { Bharathy S } \\
2017^{29}\end{array}$ & Cross sectional & Chennai & April 2013-April 2014 & Hospital based & Dog bite victims & 256 & 256 & Medium $^{a}$ \\
\hline $\begin{array}{l}\text { Sangeetha S } \\
2018^{38}\end{array}$ & Cross sectional & Salem, Tamil Nadu & February-May 2018 & Hospital based & Dog bite victims & 98 & 98 & Medium $^{a}$ \\
\hline $\begin{array}{r}\text { Vernekar } \\
2018^{39}\end{array}$ & Cross sectional & Mandur, Goa & 2017 (1 year) & $\begin{array}{l}\text { Community based } \\
\text { (Rural) }\end{array}$ & Children $\leq 16$ years of age & 536 & 18 & $\operatorname{High}^{\mathrm{a}}$ \\
\hline $\begin{array}{l}\text { Nikita Sharma } \\
2019^{30}\end{array}$ & Cross-sectional & Jaipur & May-October 2017 & Hospital based & Dog bite victims & 150 & 150 & Medium $^{\mathrm{a}}$ \\
\hline
\end{tabular}




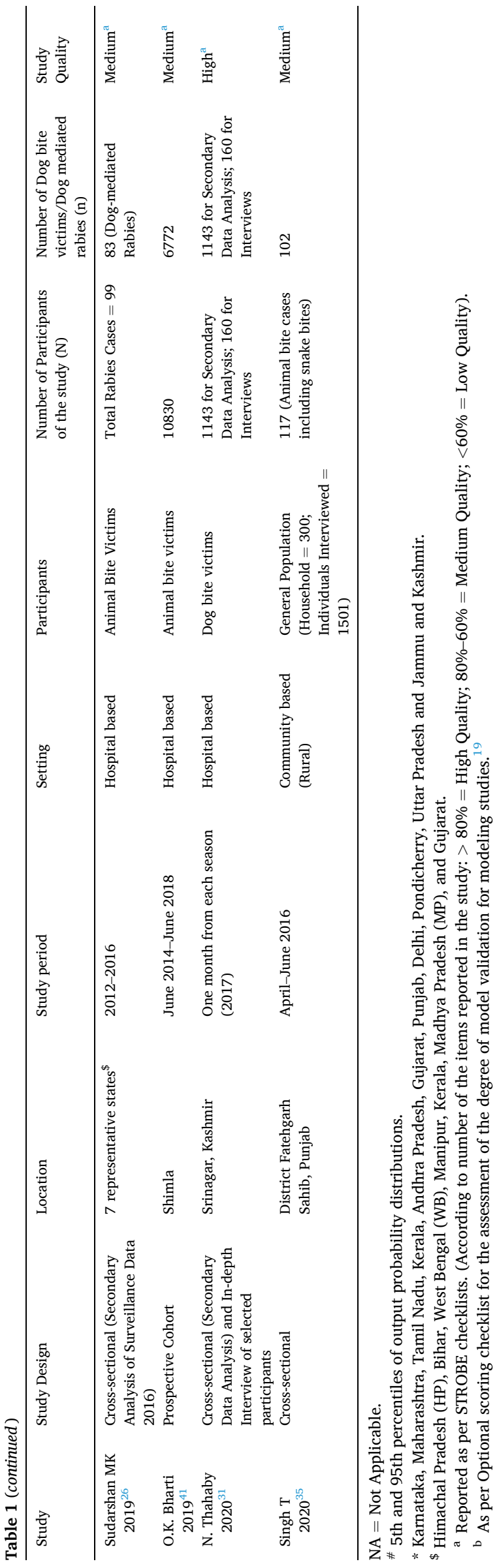

these studies. ${ }^{29,31,34,42}$ Another study reported a dog bite incidence of $1.03 \%, 8.66 \%$ and $1.7 \%$ in the age groups of $0-5,6-10$ and $11-16$ years respectively in rural parts of Goa in $2018 .^{39}$

Sex: The males in the reported studies have disproportionately experienced more dog bites than females. The studies reported the dog bites in males in a range of $57.1 \%-80.2 \% .^{23,27-32,34,38,39,42}$ The males have reported dog bites 1.6-4 times than females in all age groups.

Socio-economic status: The study conducted in Bellary in 2011 reported that $87.3 \%$ of the dog bitten children belong to upper lower and lower socio-economic class according to Modified BG Prasad criteria. ${ }^{27}$ $50 \%$ of the victims have a monthly income of $<10,000$ INR in another study conducted in Kashmir in $2020 .{ }^{31}$ However, a study conducted in rural areas of Tamil Nadu in 2013-14 reported that $73.7 \%$ of the victims were above poverty line. ${ }^{23}$

Occupation: The studies reported dog bitten students were in the range of $10 \%-34.3 \%$ of the total victims. ${ }^{28,29,31}$ The two studies conducted in rural areas reported that victims in the occupation of farmers, laborers and other field jobs were as high as $41.5 \%$ and $55.7 \%$ of the total victims. ${ }^{23,28}$ One study from urban hospital settings reported that unskilled workers contribute $30.1 \%$ of the total victims. ${ }^{29}$

\subsubsection{Description of bites}

Category of Rabies Exposure in Bites: The review reported dog bites for category II exposures in the range of $29.83 \%-82 \%$ and category III exposures in the range of $12.7 \%-70.6 \% .^{20,27,28,31,32,40}$

Site of Wounds: The majority of victims suffer animal bites on their extremities. Eight studies reported site of wounds: $55.03 \%-83.2 \%$ of the victims in these studies experienced bites on lower limb, gluteal and genital areas, while only $1 \%-13.4 \%$ of the total wounds in these studies are experienced on head, neck and face regions. ${ }^{23,27,29-32,34,38,42}$

Number of wounds: Only two studies reported number of wounds per encounter. ${ }^{23,27} 58 \%$ of the total children below 15 years of age experienced 2-4 wounds ${ }^{27}$ while $80 \%$ of the total victims in a community based study reported only 1 wound. ${ }^{23}$

Time of bite: The cross-sectional study conducted in Srinagar ${ }^{31}$ reported maximum dog bites in the evening hours $(62.9 \%)$ while the study conducted in the rural part of Maharashtra ${ }^{28}$ reported maximum dog bites between 6 a.m.-4 p.m. (82.3\%).

Months/Season of bites: A retrospective study in 2012 reported maximum dog bite cases in 41-45 weeks (14.1\%) and in pre-monsoon season $(40.8 \%){ }^{42}$ A cross-sectional study reported $45.3 \%$ of the total dog bites in the first five months of the year. ${ }^{22}$ Another cross-sectional study also reported maximum dog bites in the month selected in summer and autumn season. ${ }^{31}$

\subsubsection{Characteristics of biting dogs}

Type of biting dog: Five of the eight studies reported stray dog as the biting animal in $97.2 \%, 96.48 \%, 92.8 \%, 80.99 \%$ and $61.1 \%$ of the total cases in the respective studies. ${ }^{21,24,25,28,39}$ The prospective cohort study from Shimla reported $42.9 \%$ of the total bites by stray dogs; of which 270 bites by potentially rabid dogs and 26 by laboratory-confirmed rabid dogs and; the remaining $57.1 \%$ bites were by the pet dogs; of which $26 \%$ of the pet dogs were unimmunized stray dogs kept as pets. ${ }^{41}$ The modeling study published in 2015 reported the probability of the biting dog to be rabid is as high as 0.545 .

Vaccination status of the biting dog: Only 5 studies reported the vaccination status of the biting dogs. ${ }^{1,27,29,30,38}$ Two studies mentioned that the vaccination status of the biting dog was unknown in $52 \%$ of the total bite cases. ${ }^{27,29}$ Moreover, the dogs were vaccinated only in $8.1 \%$, $11 \%, 33.6 \%$ and $12.8 \%$ of the cases only. ${ }^{27,29,30,38}$ A modeling study reported dog vaccination coverage of $15 \%$ in the country in 2015 .

Type of bite: Four studies reported whether the dog bite was provoked or unprovoked. ${ }^{23,29,31,39}$ Two studies mentioned that the bite was unprovoked in $81.7 \%$ and $100 \%$ cases $^{23,31}$ and two other studies reported that the bite was unprovoked in $39.4 \%$ and $55.5 \%$ of the cases only. ${ }^{29,39}$ 
Table 2

Socio-demographics of dog-bite victims.

\begin{tabular}{|c|c|c|c|c|c|c|c|c|}
\hline \multirow[t]{2}{*}{ Study } & \multirow[t]{2}{*}{ Participants } & \multirow{2}{*}{$\begin{array}{l}\text { Dog bite victims } \\
\text { (n) }\end{array}$} & \multicolumn{2}{|c|}{ Age (years) } & \multirow[t]{2}{*}{ Sex } & \multicolumn{2}{|c|}{ Socio Economic Status } & \multirow[t]{2}{*}{ Occupation } \\
\hline & & & $\begin{array}{l}\text { Age } \\
\text { group }\end{array}$ & $\begin{array}{l}\text { Number } \\
(\%)\end{array}$ & & Method & SE status of participants & \\
\hline $\begin{array}{l}\text { Agarwal N } \\
2004^{32}\end{array}$ & $\begin{array}{l}\text { General } \\
\text { Population }\end{array}$ & 25 & $\begin{array}{l}<5 \\
5-14 \\
15-44 \\
45-60 \\
>60\end{array}$ & $\begin{array}{l}2 \\
6 \\
11 \\
3 \\
3\end{array}$ & $\begin{array}{l}M: F= \\
34: 15.8\end{array}$ & & & \\
\hline $\begin{array}{l}\text { Hemagiri K } \\
2012^{27}\end{array}$ & $\begin{array}{l}\text { Children }<15 \\
\text { years }\end{array}$ & 536 & $\begin{array}{l}1-3 \\
4-6 \\
7-9 \\
10-12 \\
13-15\end{array}$ & $\begin{array}{l}64 \\
115 \\
167 \\
162 \\
28\end{array}$ & $\begin{array}{l}M=382 \\
F=154\end{array}$ & $\begin{array}{l}\text { Modified BG } \\
\text { Prasad }\end{array}$ & $\begin{array}{l}\text { Upper }=11 ; \\
\text { Upper Middle }=18 \text {; Lower } \\
\text { Middle = 39; Upper Lower } \\
=248 \text {; Lower }=220\end{array}$ & \\
\hline $\begin{array}{l}\text { V. Wankhede } \\
2013^{28}\end{array}$ & $\begin{array}{l}\text { Dog bite } \\
\text { victims }\end{array}$ & 318 & $\begin{array}{l}0-5 \\
6-15 \\
16-25 \\
26-45 \\
46-60 \\
>60\end{array}$ & $\begin{array}{l}24 \\
(7.6 \%) \\
64 \\
(20.1 \%) \\
78 \\
(24.5 \%) \\
96 \\
(30.2 \%) \\
42 \\
(13.2 \%) \\
14 \\
(4.4 \%)\end{array}$ & $\begin{array}{l}M=255 \\
F=63\end{array}$ & & & $\begin{array}{l}>5=20(6.3 \%) ; \text { School Students }= \\
68(21.4 \%) ; \text { College Students }=41 \\
(12.9 \%) ; \text { Office/Shop }=23(7.2 \%) ; \\
\text { Housewife }=28(8.8 \%) ; \text { Farmer }=33 \\
(10.4 \%) ; \text { field job }=99(31.1 \%) ; \\
\text { Retired }=6(1.9 \%)\end{array}$ \\
\hline $\begin{array}{c}\text { Ayan Ghosh } \\
2014^{34}\end{array}$ & $\begin{array}{l}\text { General } \\
\text { Population }\end{array}$ & 67 & $\begin{array}{l}0-10 \\
10-20 \\
21-30 \\
31-40 \\
41-50 \\
51-60 \\
>60\end{array}$ & $\begin{array}{l}15 \\
11 \\
12 \\
8 \\
11 \\
7 \\
3\end{array}$ & $\begin{array}{l}\mathrm{M}=37 \\
\mathrm{~F}=30\end{array}$ & & & \\
\hline $\begin{array}{l}\text { Venkatesan } \\
2014^{23}\end{array}$ & $\begin{array}{l}\text { Animal bite } \\
\text { victims (N = } \\
12947)\end{array}$ & 289 & $\begin{array}{l}18-30 \\
18-30 \\
41-50 \\
>50\end{array}$ & $\begin{array}{l}66 \\
60 \\
66 \\
97\end{array}$ & $\begin{array}{l}\mathrm{M}=174 \\
\mathrm{~F}=115\end{array}$ & Ration Card & $\begin{array}{l}\mathrm{APL}=213 \\
\mathrm{BPL}=72 ; \\
\text { No ration card }=4\end{array}$ & $\begin{array}{l}\text { Housewife }=37 ; \text { Farmer }=91 ; \\
\text { Labourer }=70 ; \text { Others (Not reported } \\
\text { in study) }=91\end{array}$ \\
\hline $\begin{array}{l}\text { V. Khan } \\
2014^{42}\end{array}$ & $\begin{array}{l}\text { Dog bite } \\
\text { victims }\end{array}$ & 938 & $\begin{array}{l}0-5 \\
6-10 \\
11-15 \\
16-20 \\
21-25 \\
26-30 \\
31-35 \\
36-40 \\
41-45 \\
>46\end{array}$ & $\begin{array}{l}15.6 \% \\
18.5 \% \\
5.5 \% \\
9.7 \% \\
9.7 \% \\
8.1 \% \\
11.1 \% \\
6.2 \% \\
5.7 \% \\
10.0 \%\end{array}$ & $\begin{array}{l}\mathrm{M}= \\
74.9 \% \\
\mathrm{~F}= \\
25.1 \%\end{array}$ & & & \\
\hline $\begin{array}{l}\text { Bharathy S } \\
2017^{29}\end{array}$ & $\begin{array}{l}\text { Dog bite } \\
\text { victims }\end{array}$ & 256 & $\begin{array}{l}0-10 \\
10-20 \\
21-30 \\
31-40 \\
41-50 \\
51-60 \\
>60\end{array}$ & $\begin{array}{l}30 \\
55 \\
52 \\
37 \\
31 \\
30 \\
21\end{array}$ & $\begin{array}{l}M=184 \\
F=72\end{array}$ & & & $\begin{array}{l}\text { Student }=87 ; \text { Business }=19 ; \\
\text { Housewife }=26 ; \text { Employee }=47 \\
\text { Unskilled }=77\end{array}$ \\
\hline $\begin{array}{c}\text { Sangeetha S } \\
2018^{38}\end{array}$ & $\begin{array}{l}\text { Dog bite } \\
\text { victims }\end{array}$ & 98 & $\begin{array}{l}<5 \\
5-25 \\
26-45 \\
46-65 \\
>65\end{array}$ & $\begin{array}{l}1 \\
33 \\
32 \\
30 \\
2\end{array}$ & $\begin{array}{l}M=56 \\
F=42\end{array}$ & $\begin{array}{l}\text { Modified BG } \\
\text { Prasad }\end{array}$ & $\begin{array}{l}\text { Middle Upper }=17 \\
\text { Middle Lower }=11 \\
\text { Lower Upper }=41 \\
\text { Lower Lower }=29\end{array}$ & $\begin{array}{l}\text { House wife }=22 ; \\
\text { Student }=25 ; \text { Weaver }=15 ; \\
\text { Coolie }=11 ; \\
\text { Agriculture }=12 ; \\
\text { Other }=13\end{array}$ \\
\hline $\begin{array}{r}\text { Vernekar } \\
2018^{39}\end{array}$ & $\begin{array}{l}\text { Children } \leq 16 \\
\text { years of age }\end{array}$ & 18 & $\begin{array}{l}0-5 \\
6-10 \\
11-16\end{array}$ & $\begin{array}{l}2 \\
13 \\
3\end{array}$ & $\begin{array}{l}M=11 \\
F=7\end{array}$ & & & \\
\hline $\begin{array}{l}\text { Nikita } \\
\text { Sharma } \\
2019^{30}\end{array}$ & $\begin{array}{l}\text { Dog bite } \\
\text { victims }\end{array}$ & 150 & $\begin{array}{l}<5 \\
5-25 \\
26-45 \\
46-65\end{array}$ & $\begin{array}{l}2(1.3 \%) \\
52 \\
(34.5 \%) \\
49 \\
(32.9 \%) \\
47 \\
(31.3 \%)\end{array}$ & $\begin{array}{l}M=87 \\
F=63\end{array}$ & & & \\
\hline $\begin{array}{l}\text { N. Thahaby } \\
2020^{31}\end{array}$ & $\begin{array}{l}\text { Dog bite } \\
\text { victims }\end{array}$ & $\begin{array}{l}1143 \text { (Secondary } \\
\text { Data Analysis); } 40 \\
\text { (Indepth } \\
\text { Interviews) }\end{array}$ & $\begin{array}{l}1-10 \\
10-20 \\
20-30 \\
30-40 \\
40-50 \\
50-60 \\
>60\end{array}$ & $\begin{array}{l}130 \\
173 \\
223 \\
305 \\
145 \\
94 \\
73\end{array}$ & $\begin{array}{l}M=849 \\
F=294\end{array}$ & $\begin{array}{l}\text { Monthly } \\
\text { Income in } \\
\text { INR }(n=40)\end{array}$ & $\begin{array}{l}>=80,000=0 \\
50,000-70,000=4 ; \\
40,000-50,000=10 ; \\
20,000-30,000=6 ;<= \\
10,000=20\end{array}$ & $\begin{array}{l}\text { Students }=4(10 \%) ; \text { Daily wagers }= \\
6(15 \%) ; \text { Laborers = } 20(50 \%) ; \\
\text { Businessman = } 10(25 \%) ;\end{array}$ \\
\hline
\end{tabular}

$\mathrm{M}=$ Male, $\mathrm{F}=$ Female, $\mathrm{APL}=$ Above Poverty Line, $\mathrm{BPL}=$ Below Poverty Line, $\mathrm{INR}=$ Indian National Rupee. 


\subsubsection{Description of rabies}

The nationwide multi-centric survey conducted by Association for Prevention and Control of Rabies in India (APCRI) in 2003 reported that 226 out of 235 rabies cases $(96.2 \%)$ due to dog bites and majority of these deaths $(75.2 \%)$ occurred due to the bite of stray dogs. ${ }^{37}$ Furthermore, the multi-centric survey conducted by APCRI in 2017 reported 83 out of 99 rabies cases (83.8\%) due to dog bites. ${ }^{26}$ Out of the 140 rabies deaths reported in the Million Death Study (MDS) between 2001 and 2003, total number of Dog mediated rabies was 136 (Male $=84$, Female $=52) .{ }^{4}$ However, no rabies deaths were reported from Andaman \& Nicobar and Lakshadweep Islands in the APCRI survey in 2003 and Dadar \& Nagar Haveli in 2012..$^{37,42}$ The laboratory based surveillance study on the clinical samples received from 128 patients with suspected human rabies from 11 states and Union Territories between 2012 and 2016 reported 19 laboratory confirmed dog-mediated rabies cases. ${ }^{36}$ Out of these 19 cases, number of paralytic, encephalitic and atypical forms were 10, 8 and 1 respectively. The male to female ratio was 17:2 and 13 of the cases were below 30 years of age. The incubation period ranged between 15 days -5 years and only 4 people survived till the end of observation period ( 5 years) of the study. The minimum period of survival was 2 days only. ${ }^{36}$

The findings from a simulation model published in 2005 reported a total number 19,713 (4192-39,733; 5th and 95th percentiles of output probability distributions) annual deaths due to canine rabies in India and estimated deaths per 100,000 people to be 0.37 and 2.49 due to canine rabies in urban and rural India respectively. ${ }^{43}$ Another modeling study published in 2015 estimated 20,847 (95\% CI: 7000-55000) annual deaths due to canine rabies in the country. ${ }^{1}$

\subsection{Economic burden}

Ten studies reported economic outcomes: 3 studies $^{44-46}$ reported direct costs, 1 study ${ }^{47}$ reported programmatic cost of implementation, 4 studies $^{1,48-50}$ reported both direct and indirect costs and 2 studies ${ }^{51,52}$ reported resource utilization. The costs reported in these studies are converted in 2020 International Dollars' value and presented in this paper.

A detailed description of the included studies is mentioned in Table 4.

\subsubsection{Resource utilization and cost of anti-rabies vaccines}

The cost per vial of ARV (anti-rabies vaccine) for a 5 dose IM PEP regimen in a study conducted in a tertiary care government hospital in Haryana in 2008-09 was USD 17.75 and cost of full PEP per person was USD 93.17. ${ }^{49}$ The procurement cost of $1 \mathrm{ml}$ vial of IM ARV was estimated to be USD 5.38 and $1 \mathrm{ml}$ of ID ARV was estimated to be USD 26.02 in a study conducted in Tamil Nadu to calculate the implementation cost of interventions to control rabies in $2012 .{ }^{47}$ One study conducted in a tertiary care hospital in Kerala calculated cost of PEP for U-TRCID Updated Thai Red Cross Intra Dermal regime (injection of $0.1 \mathrm{ml}$ on two deltoids on days 0-3-7-28) in 2013. ${ }^{44}$ It estimated the cost of vaccine per person to be USD 27 for PEP and USD 16.87 for re-exposure prophylaxis (Re-EP) considering the amount of $0.8 \mathrm{ml}$ of vaccine is required for PEP and $0.2 \mathrm{ml}$ is required for Re-EP and taking the cost of a $0.5 \mathrm{ml}$ vial as USD 16.87 (government price). ${ }^{44}$

One study assessed the benefits accrued due to a switch from Essen Intramuscular regimen (EIM; $1 \mathrm{~mL}$ of the vaccine on deltoid on days 0-37-14-28) to U-TRCID in regimen in 2011 in a government hospital in New Delhi. ${ }^{45}$ It reported the cost per unit of vaccine to be USD 5.05 for EIM regimen and USD 3.76 for U-TRCID regimen. ${ }^{45}$

Another article studied the cost variation among various brands of anti-rabies vaccines in India in $2020 .^{46}$ The price per vial of vaccine for different brands ranged from USD 16.64 to USD 18.54 and the percentage variation was calculated to be $13.2 \%$.

Table 5 provides details of these studies.

\subsubsection{Resource utilization and costs of rabies immunoglobulins}

The recommended dose of Equine Rabies Immunoglobulins (ERIG) is $40 \mathrm{IU} / \mathrm{Kg}$ body weight and Human Rabies Immunoglobulins (HRIG) is $20 \mathrm{IU} / \mathrm{Kg}$ body weight in non-immunized category III exposures. As $1 \mathrm{ml}$ of ERIG contains $300 \mathrm{IU}$ and $1 \mathrm{ml}$ of HRIG contains $150 \mathrm{IU}$, therefore, the proportion of immunoglobulin is same in both recommended RIG. The required amount per person is $0.1333 \mathrm{ml} / \mathrm{kg}$ bodyweight. ${ }^{46}$

One study conducted in Kerala in 2013 reported the cost of a vial of ERIG ( $5 \mathrm{ml}$ ) to be USD 29.23 (market price) and the maximum cost person to be USD $54 .{ }^{44}$ The same study also reported the market cost per vial ( $2 \mathrm{ml}$ ) of HRIG of two different brands to be USD 186.5 and USD 434.15 respectively and maximum cost per person to be USD $431.99 .{ }^{44}$ Another study evaluated the cost of RIG for a $60 \mathrm{~kg}$ adult in 2020 reported the cost of 1 vial $(5 \mathrm{ml})$ of ERIG and HRIG to be USD 33.55 and USD 279.27 respectively and cost of ERIG and HRIG for a $60 \mathrm{~kg}$ adult to be USD 268.39 and USD 1117.08 respectively. ${ }^{46}$

The estimated cost of procuring 1500 IU of ERIG in a study in Tamil Nadu in 2012 was USD 41.71 and the total cost of procurement for entire population ( $\mathrm{n}=72,138,958)$ was USD 5.91 million. ${ }^{47}$ The average quantity of ERIG consumed in 140 dog bite victims in a Shimla based study was $2.5 \mathrm{ml}$ in 2016 and there has been $80 \%$ reduction in the dose of ERIG due to local infilteration in wounds without systemic IM administration. ${ }^{51}$ Another study conducted in Shimla on patients ( $\mathrm{n}=$ 26) bitten by laboratory proven dogs has reported wound only injection of ERIG in the range of $0.5-6.5 \mathrm{ml}$ and $40-600$ IU between July 2014-July 2016 has resulted in survival of all the patients in the observation period. ${ }^{51}$

Table 5 provides details of these studies.

\subsubsection{Cost of treatment regimens and modalities}

A study conducted in 2003 estimated the cost of four rabies postexposure regimens in a multi-centric study. ${ }^{48}$ It reported the total cost of full PEP in TRC-ID (Thai Red Cross Intradermal) PVRV 0.5 ml IM Dose regimen in public and private facility to be USD 181.01 and USD 209.45; TRC 1/10th of IM Dose regimen in public and private facility to be USD 164.76 and USD 178.98; Essen IM in public and private facility to be USD 250.07 and USD 338.92 and; Zagreb IM (2 vials on day 0, 1 vial on days 7 and 21) in public and private facility to be USD 176.06 and USD 247.15 respectively.

The cost for providing ARV alone per dog bite and annual programmatic costs in Tamil Nadu in 2012 was estimated to be USD 3.44 and USD 0.8 million respectively, while the cost for providing ARV in combination with ERIG per dog bite and annual programmatic costs was estimated to be USD 12.62 and USD 2.5 million respectively. ${ }^{47}$

Another article studied the treatment cost under various categories for a $60 \mathrm{~kg}$ adult in India in $2020 .^{46}$ The cost of PrEP (three intramuscular doses of ARV on days 0-7-21/28) was calculated to be USD 55.57 (assumed cost of 1 vial is USD 18.49). The cost of Re-EP (PrEP +2 doses of ARV after exposure) was calculated to be USD 92.46. Since, no vaccination is required, there is no cost involved in Category I exposure. Under Essen Regimen, category II exposure requires 5 complete doses of IM ARV, the cost was estimated to be USD 92.46 and category III exposures require both 5 doses of ARVs along with RIG, the cost of PEP with ERIG and HRIG was estimated to be USD 360.84 and USD 1209.53 respectively. ${ }^{46}$

A health facility based study conducted in six states from May 2017 to January 2018 reported the cost of PEP from government perspectives. ${ }^{50}$ The cost of providing free of cost IMRV with ERIG for each category III exposure was USD 19.74 and IMRV for category II exposure was USD 10.39. The cost of providing free of cost IDRV with ERIG for 
Table 3

Description of bites.

\begin{tabular}{|c|c|c|c|c|c|c|c|c|}
\hline Study & Participants & $\begin{array}{l}\text { Dog bite } \\
\text { victims (n) }\end{array}$ & $\begin{array}{l}\text { Category of } \\
\text { Bite }\end{array}$ & Site of bite & $\begin{array}{l}\text { Number of } \\
\text { bite wounds }\end{array}$ & Type of Dog & $\begin{array}{l}\text { Vaccination } \\
\text { Status of } \\
\text { biting Dog }\end{array}$ & Type of Bite \\
\hline $\begin{array}{l}\text { Agarwal N } \\
2004^{32}\end{array}$ & $\begin{array}{l}\text { General } \\
\text { Population }\end{array}$ & 25 & $\begin{array}{l}\text { Cat } 1=5 ; \\
\text { Cat } 2=12 ; \\
\text { Cat } 3=8\end{array}$ & $\begin{array}{l}\text { Head, Neck }=2 \text {; Hands } \\
=4 ; \text { Legs }=18 ; \text { Other }= \\
1\end{array}$ & & & & \\
\hline $\begin{array}{l}\text { Teena M } \\
2012^{20}\end{array}$ & $\begin{array}{l}\text { Animal bite } \\
\text { victims }\end{array}$ & 225 & $\begin{array}{l}\text { Cat } 2=92 \\
\text { Cat } 3=133\end{array}$ & & & & & \\
\hline $\begin{array}{l}\text { Hemagiri K } \\
2012^{27}\end{array}$ & $\begin{array}{l}\text { Children }<15 \\
\text { years }\end{array}$ & 536 & $\begin{array}{l}\text { Cat } 1= \\
117 ; \text { Cat } 2 \\
=351 ; \text { Cat } \\
3=68\end{array}$ & $\begin{array}{l}\text { Head \& Neck }=32 ; \\
\text { Upper Limb }=93 ; \text { Hand } \\
=84 ; \text { Trunk }=32 ; \\
\text { Genital Area }=5 ; \\
\text { Gluteal Area }=65 ; \\
\text { Lower Limb }=225\end{array}$ & $\begin{array}{l}\text { One }=198 ; \\
\text { Two }- \text { Four }= \\
311 ;>\text { Five } \\
=27\end{array}$ & & $\begin{array}{l}\text { Yes }=59 ; \text { No } \\
=197 ; \\
\text { Unknown }= \\
280\end{array}$ & \\
\hline $\begin{array}{l}\text { Shah V } \\
2012^{21}\end{array}$ & $\begin{array}{l}\text { Animal bite } \\
\text { victims }\end{array}$ & 1109 & & & & $\begin{array}{l}\text { Stray Dog = 1070; Pet } \\
\text { Dog = } 39\end{array}$ & & \\
\hline $\begin{array}{l}\text { V. } \\
\text { Wankhede } \\
2013^{28}\end{array}$ & $\begin{array}{l}\text { Dog bite } \\
\text { victims }\end{array}$ & 318 & $\begin{array}{l}\text { Cat } 1=02 ; \\
\text { Cat } 2= \\
126 ; \text { Cat } 3 \\
=190\end{array}$ & & & $\begin{array}{l}\text { Stray Dog }=309(97.2 \%) \\
\text { Pet Dog }=9(2.8 \%)\end{array}$ & & \\
\hline $\begin{array}{l}\text { Ayan Ghosh } \\
2014^{34}\end{array}$ & $\begin{array}{l}\text { General } \\
\text { Population }\end{array}$ & 67 & & $\begin{array}{l}\text { Face }=09 ; \text { Trunk }=16 \\
\text { Extremities }=42\end{array}$ & & & & \\
\hline $\begin{array}{l}\text { Venkatesan } \\
\text { M } 2014^{23}\end{array}$ & $\begin{array}{l}\text { Animal bite } \\
\text { victims }(\mathrm{N}= \\
12947)\end{array}$ & 289 & & $\begin{array}{l}\text { Head and Neck }=3 \\
(1 \%) ; \text { Trunk }=1(0.3 \%) ; \\
\text { Lower limb }=233 \\
(80.6 \%) ; \text { Upper limb }= \\
43(14.8 \%) ; \text { Others }=9 \\
(3.1 \%)\end{array}$ & $\begin{array}{l}\text { One }=233 \\
(80.6 \%) \\
\text { Two }=38 \\
(13.1 \%) ;> \\
\text { Three }=18 \\
(6.3 \%)\end{array}$ & & & $\begin{array}{l}\text { Provoked = 53 } \\
(18.3 \%) ; \\
\text { Unprovoked }= \\
236(81.7 \%)\end{array}$ \\
\hline $\begin{array}{l}\text { V. Khan } \\
2014^{42}\end{array}$ & $\begin{array}{l}\text { Dog bite } \\
\text { victims }\end{array}$ & 938 & & $\begin{array}{l}\text { Head and face }=3.3 \% ; \\
\text { Abdomen }=2.8 \% ; \\
\text { Lower } \operatorname{limb}=63.5 \% \\
\text { Upper } \operatorname{limb}=24.4 \% \\
\text { Hands }=5.9 \%\end{array}$ & & & & \\
\hline $\begin{array}{l}\text { Ramesh } \\
\text { Masthi } \\
2015^{40}\end{array}$ & $\begin{array}{l}\text { Animal bite } \\
\text { victims (All } \\
\text { were dog } \\
\text { bites) }\end{array}$ & 27 & $\begin{array}{l}\text { Cat } 2=22 \\
\text { Cat } 3=05\end{array}$ & & & & & \\
\hline $\begin{array}{l}\text { Acharya R } \\
2016^{24}\end{array}$ & $\begin{array}{l}\text { Animal Bite } \\
\text { Victims }\end{array}$ & 10287 & & & & $\begin{array}{l}\text { Stray Dog }=8332 ; \text { Pet } \\
\text { Dog }=1955\end{array}$ & & \\
\hline $\begin{array}{l}\text { Marathe N } \\
2016^{25}\end{array}$ & $\begin{array}{l}\text { Animal Bite } \\
\text { Victims }\end{array}$ & 389 & & & & $\begin{array}{l}\text { Stray Dog }=361 ; \text { Pet Dog } \\
=28\end{array}$ & & \\
\hline $\begin{array}{l}\text { Bharathy S } \\
2017^{29}\end{array}$ & $\begin{array}{l}\text { Dog bite } \\
\text { victims }\end{array}$ & 256 & & $\begin{array}{l}\text { Face }=8 ; \text { Trunk }=9 ; \\
\text { Lower Limb }=153 \\
\text { Upper } \operatorname{limb}=86\end{array}$ & & $\begin{array}{l}\text { Stray Dog }=47 \% \text {; Pet Dog } \\
=53 \%\end{array}$ & $\begin{array}{l}\text { Yes }=86 ; \text { No } \\
=35 ; \\
\text { Unknown }= \\
135\end{array}$ & $\begin{array}{l}\text { Provoked = } \\
155 ; \\
\text { Unprovoked = } \\
101\end{array}$ \\
\hline $\begin{array}{l}\text { Sangeetha S } \\
2018^{38}\end{array}$ & $\begin{array}{l}\text { Dog bite } \\
\text { victims }\end{array}$ & 98 & & & & $\begin{array}{l}\text { Stray Dog }=24 ; \text { Pet Dog }= \\
74\end{array}$ & $\begin{array}{l}\text { Yes }=8 ; \text { No }= \\
90\end{array}$ & \\
\hline $\begin{array}{l}\text { Vernekar } \\
2018^{39}\end{array}$ & $\begin{array}{l}\text { Children } \leq 16 \\
\text { years of age }\end{array}$ & 18 & & $\begin{array}{l}\text { Lower limb }=12 ; \text { Upper } \\
\text { limb }=3 ; \text { Chest/ } \\
\text { abdomen/back }=2 ; \\
\text { Head/neck/face }=1\end{array}$ & & Stray $=11 ;$ Pet $=7$ & & $\begin{array}{l}\text { Provoked =8; } \\
\text { unprovoked }= \\
10\end{array}$ \\
\hline $\begin{array}{l}\text { Nikita } \\
\text { Sharma } \\
2019^{30}\end{array}$ & $\begin{array}{l}\text { Dog bite } \\
\text { victims }\end{array}$ & 150 & & $\begin{array}{l}\text { Head, Neck, face }=4 \\
(2.4 \%) ; \text { Trunk }=5 \\
(3.2 \%) ; \text { Upper limb }= \\
17(11.2 \%) \text {; Right lower } \\
\text { limb }=70(46.7 \%) \text {; Left } \\
\text { lower limb }=54 \\
(36.5 \%)\end{array}$ & & $\begin{array}{l}\text { Stray Dog = } 56(37.5 \%) \\
\text { Pet Dog }=94(62.5 \%)\end{array}$ & $\begin{array}{l}\text { Yes }=19 \\
(12.8 \%) ; \text { No } \\
=131 \\
(87.2 \%)\end{array}$ & \\
\hline $\begin{array}{l}\text { O.K. Bharti } \\
2019^{41}\end{array}$ & $\begin{array}{l}\text { Animal bite } \\
\text { victims }\end{array}$ & 6772 & & & & $\begin{array}{l}\text { Stray Dogs }=2909 \text { ( } 270 \\
\text { potentially rabid dogs and } \\
26 \text { laboratory-confirmed } \\
\text { rabid dogs; Pet Dogs }= \\
3863 \text { (26\%of these pet } \\
\text { dogs were unimmunized } \\
\text { stray dogs kept as pets. }\end{array}$ & & \\
\hline $\begin{array}{l}\text { N. Thahaby } \\
2020^{31}\end{array}$ & $\begin{array}{l}\text { Dog bite } \\
\text { victims }\end{array}$ & $\begin{array}{l}1143 \\
\text { (Secondary } \\
\text { Data Analysis); } \\
40 \text { (Indepth } \\
\text { Interviews) }\end{array}$ & $\begin{array}{l}\text { Cat } 2= \\
341 ; \text { Cat } 3 \\
=802\end{array}$ & $\begin{array}{l}\text { Face }=19(1.66 \%) ; \\
\text { Hands, arms \& } \\
\text { shoulders }=236 \\
(20.64 \%) ; \text { Legs }=647 \\
(56.60 \%) ; \text { Knees, thighs } \\
=104(9.09 \%) ; \\
\text { Buttocks = } 113 \\
(9.88 \%) ; \text { Abdomen \& } \\
\text { back }=24(2.09 \%)\end{array}$ & & & & $\begin{array}{l}\text { Provoked }= \\
0(0.00 \%) ; \\
\text { Unprovoked }= \\
40(100 \%)\end{array}$ \\
\hline
\end{tabular}


Table 4

Characteristics of studies included in the review for Economic Outcome.

\begin{tabular}{|c|c|c|c|c|c|c|c|c|}
\hline Study & Study Design & Location & Costs & Participants & Study period & $\begin{array}{l}\text { Number of } \\
\text { Participants of the } \\
\text { study (N) }\end{array}$ & $\begin{array}{l}\text { Number of Dog bite } \\
\text { victims/Dog mediated } \\
\text { rabies (n) }\end{array}$ & $\begin{array}{l}\text { Quality Assessment (Items } \\
\text { Reported as per CHEC/ } \\
\text { CHEERS checklist) }\end{array}$ \\
\hline $\begin{array}{l}\text { A. Goswami } \\
2005^{48}\end{array}$ & Prospective, Observational Study & Multicentric & Direct and Indirect & Dog bite victims & June-July 2003 & 428 & 428 & $10 / 19^{\mathrm{a}}$ \\
\hline Jyoti $2010^{49}$ & $\begin{array}{l}\text { Record based (Secondary Data } \\
\text { Analysis) }\end{array}$ & $\begin{array}{l}\text { Rohtak, } \\
\text { Haryana }\end{array}$ & Direct and Indirect & Animal Bite Victims & $\begin{array}{l}\text { 1st June 2008-31st } \\
\text { May } 2009\end{array}$ & 3617 & 2912 & $8 / 19^{\mathrm{a}}$ \\
\hline $\begin{array}{l}\text { Abbas } \\
2014^{46}\end{array}$ & $\begin{array}{l}\text { Cost of implementation, Cost } \\
\text { Analysis, Modeling }\end{array}$ & Tamil Nadu & $\begin{array}{l}\text { Direct (Cost of } \\
\text { Implementation) }\end{array}$ & Dog bite victims & 2012 & $\begin{array}{l}\text { TN population: } \\
72138958\end{array}$ & $\begin{array}{l}1356 \text { per } 100000 \\
\text { population }\end{array}$ & $13 / 19^{\mathrm{a}}$ \\
\hline $\begin{array}{l}\text { Sajna, MV } \\
2014^{44}\end{array}$ & $\begin{array}{l}\text { Cross-sectional, record based } \\
\text { study, Cost Analysis }\end{array}$ & Thrissur, Kerala & Direct & Animal Bite Victims & $\begin{array}{l}\text { 1st week of May } \\
2013\end{array}$ & 213 & 134 & $9 / 19^{\mathrm{a}}$ \\
\hline $\begin{array}{l}\text { Hampson K } \\
2015^{1}\end{array}$ & $\begin{array}{l}\text { Modeling Study (Probability } \\
\text { decision tree framework) }\end{array}$ & $\begin{array}{l}\text { Global and } \\
\text { country level }\end{array}$ & Direct and Indirect & $\begin{array}{l}\text { Based on data on dog } \\
\text { (canine) bite victims }\end{array}$ & 2015 & $\mathrm{NA}$ & $\begin{array}{l}20,847 \text { [95\% CI: } \\
7000-55,000]\end{array}$ & $19 / 24^{\mathrm{b}}$ \\
\hline $\begin{array}{l}\text { O. K. Bharti } \\
2016^{51}\end{array}$ & Prospective Cohort & Shimla & Resource Utilization & Dog bite victims & $\begin{array}{l}\text { June } 2014 \text { to July } \\
2016\end{array}$ & 140 & 140 & $10 / 16^{\mathrm{a}, \mathrm{c}}$ \\
\hline $\begin{array}{l}\text { O. K. Bharti } \\
2017^{52}\end{array}$ & Prospective Cohort & Shimla & Resource Utilization & $\begin{array}{l}\text { Rabid Dog bite } \\
\text { victims }\end{array}$ & $\begin{array}{l}\text { June } 2014 \text { to July } \\
2016\end{array}$ & 26 & 26 & $11 / 16^{\mathrm{a}, \mathrm{c}}$ \\
\hline $\begin{array}{l}\text { Ravish } \\
2019^{50}\end{array}$ & $\begin{array}{l}\text { Cross-sectional study, Cost } \\
\text { Analysis }\end{array}$ & Multicentric & Direct and Indirect & Animal Bite Victims & $\begin{array}{l}\text { May 2017-January } \\
2018\end{array}$ & 529 & & $9 / 19^{\mathrm{a}}$ \\
\hline $\begin{array}{c}\text { Kundu BK } \\
2019^{45}\end{array}$ & $\begin{array}{l}\text { Retrospective (A comparison } \\
\text { between two regimens due to a } \\
\text { switch) }\end{array}$ & New Delhi & Direct & Animal Bite Victims & $\begin{array}{l}2010 \\
2012\end{array}$ & $\begin{array}{l}N(2010)=12619 \\
N(2012)=16904\end{array}$ & & $12 / 19^{\mathrm{a}}$ \\
\hline $\begin{array}{r}\text { Sujitha P } \\
2020^{46}\end{array}$ & $\begin{array}{l}\text { Record based Study, Secondary } \\
\text { Database Analysis, Cost Analysis }\end{array}$ & India & Direct & Animal Bite Victim & $\begin{array}{l}\text { November } 2019 \text { to } \\
\text { April } 2020\end{array}$ & \multicolumn{2}{|c|}{ Cost variation calculated for a $60 \mathrm{~kg}$ adult } & $12 / 19^{\mathrm{a}}$ \\
\hline
\end{tabular}

NA $=$ Not Applicable

${ }^{a}$ Critical Appraisal through Consensus Health Economic Criteria (CHEC) list.

${ }^{\mathrm{b}}$ Critical Appraisal through Consolidated Health Economics Evaluation Reporting Standards (CHEERS) checklist.

c 3 items were not applicable. 


\begin{tabular}{|c|c|c|c|c|c|c|c|c|c|c|c|c|c|c|c|c|}
\hline \multirow[t]{3}{*}{ Study } & \multicolumn{6}{|c|}{ ARV (Anti-Rabies Vaccines) } & \multicolumn{5}{|c|}{ ERIG (Equine Rabies Immunoglobulins) } & \multicolumn{5}{|c|}{ HRIG (Human Rabies Immunoglobulins) } \\
\hline & \multirow[t]{2}{*}{ Regimen } & \multirow{2}{*}{$\begin{array}{l}\text { Amount pe } \\
\text { person }\end{array}$} & \multicolumn{2}{|c|}{ rCost per vial } & \multicolumn{2}{|c|}{ Cost per person } & \multirow{2}{*}{$\begin{array}{l}\text { Amount per } \\
\text { nerson }\end{array}$} & \multicolumn{2}{|l|}{ Cost per vial } & \multicolumn{2}{|c|}{ Cost per person } & \multirow{2}{*}{$\begin{array}{l}\text { Amount per } \\
\text { person }\end{array}$} & \multicolumn{2}{|l|}{ Cost per vial } & \multicolumn{2}{|c|}{ Cost per person } \\
\hline & & & $\begin{array}{l}\text { Original } \\
\text { Study }\end{array}$ & $\begin{array}{l}\text { Conversion in } \\
\text { to } 2020 \text { USD }\end{array}$ & $\begin{array}{l}\text { Original } \\
\text { Study }\end{array}$ & $\begin{array}{l}\text { Conversion in } \\
\text { to } 2020 \text { USD }\end{array}$ & & Original Study & $\begin{array}{l}\text { Conversion in } \\
\text { to } 2020 \text { USD }\end{array}$ & $\begin{array}{l}\text { Original } \\
\text { Study }\end{array}$ & $\begin{array}{l}\text { Conversion in } \\
\text { to } 2020 \text { USD }\end{array}$ & & $\begin{array}{l}\text { Original } \\
\text { Study }\end{array}$ & $\begin{array}{l}\text { Conversion in } \\
\text { to } 2020 \text { USD }\end{array}$ & $\begin{array}{l}\text { n Original } \\
\text { Study }\end{array}$ & $\begin{array}{l}\text { Conversion in } \\
\text { to } 2020 \text { USD }\end{array}$ \\
\hline $\begin{array}{l}\text { Jyoti } \\
2010^{49}\end{array}$ & $\begin{array}{l}5 \text { dose IN } \\
\text { PEP }\end{array}$ & & $\begin{array}{l}\text { INR } 200 \\
\text { (USD } \\
13.65)\end{array}$ & 17.75 & $\begin{array}{l}\text { INR } 1050 \\
\text { (USD } \\
71.64 \text { ) }\end{array}$ & 93.17 & & & & & & & & & & \\
\hline $\begin{array}{l}\text { Abbas } \\
2014^{47}\end{array}$ & ID ARV & & $\begin{array}{l}\text { INR } 363 \\
\text { (USD } \\
21.44)^{\mathrm{a}}\end{array}$ & 26.02 & & & & $\begin{array}{l}\text { INR } 582 \text { for } \\
\text { procurement of } \\
1500 \text { IU (USD } \\
34.37 \text { ) }\end{array}$ & 41.71 & & & & & & & \\
\hline & IM ARV & & $\begin{array}{l}\text { INR } 75 \\
\text { (USD } \\
4.43)^{\mathrm{a}}\end{array}$ & 5.38 & & & & & & & & & & & & \\
\hline $\begin{array}{l}\text { Sajna MV } \\
2014^{44}\end{array}$ & $\begin{array}{l}\text { JU TRC } \\
\text { PEP }\end{array}$ & $0.8 \mathrm{ml}$ & $\begin{array}{l}\text { INR 250 } \\
\text { (USD } \\
14.76) \#\end{array}$ & 16.87 & $\begin{array}{l}\text { INR } 400 \\
\text { (USD } \\
23.63 \text { ) }\end{array}$ & 27 & $0.133 \mathrm{ml} / \mathrm{kg}$ & $\begin{array}{l}\text { INR } 433 \text { for } 5 \mathrm{ml} \\
\text { (USD 25.57) }\end{array}$ & 29.23 & $\begin{array}{l}\text { INR } 800 \\
\text { (USD } \\
47.24)^{\mathrm{a}}\end{array}$ & 54 & $0.133 \mathrm{ml} / \mathrm{kg}$ & $\begin{array}{l}\text { B1 }(2 \mathrm{ml})= \\
\text { INR 2763 } \\
\text { (USD 163.16) }\end{array}$ & B1 = 186.50 & $\begin{array}{l}\text { INR } 6400 \\
\text { (USD } \\
377.94)^{\prime \prime}\end{array}$ & 431.99 \\
\hline & $\begin{array}{l}\text { U TRC Re } \\
\text { EP }\end{array}$ & e- $0.2 \mathrm{ml}$ & & & $\begin{array}{l}\text { INR } 250 \\
\text { (USD } \\
14.76 \text { ) }\end{array}$ & 16.87 & & & & & & & $\begin{array}{l}\text { B2 }(2 \mathrm{ml})= \\
\text { INR } 6432 \\
\text { (USD 379.83) }\end{array}$ & B2 = 434.15 & & \\
\hline $\begin{array}{l}\text { O. K. } \\
\text { Bharti } \\
2016^{51}\end{array}$ & & & & & & & $\begin{array}{l}\text { Average quantity } \\
\text { of ERIG } \\
\text { consumed }=2.5 \\
\mathrm{ml}\end{array}$ & $\begin{array}{l}80 \% \text { reduction in } \\
\text { wounds without } \mathrm{s}\end{array}$ & $\begin{array}{l}\text { the dose of ERIC } \\
\text { ystemic IM adm }\end{array}$ & $\begin{array}{l}\text { G due to loca } \\
\text { inistration }\end{array}$ & al infilteration in & & & & & \\
\hline $\begin{array}{l}\text { O. K. } \\
\text { Bharti } \\
2017^{52}\end{array}$ & & & & & & & $\begin{array}{l}\text { Range: } 0.5-6.5 \mathrm{~m} \\
\text { of eRIG; } 40-600 \\
\text { IU }\end{array}$ & & & & & & & & & \\
\hline $\begin{array}{l}\text { Kundu } \\
\text { BK } \\
2019^{45}\end{array}$ & $\begin{array}{l}\text { EIM } \\
\text { U TRC }\end{array}$ & & & & $\begin{array}{l}\text { USD } 4.23 \\
\text { USD } 3.15\end{array}$ & $\begin{array}{l}5.05 \\
3.76\end{array}$ & & & & & & & & & & \\
\hline $\begin{array}{r}\text { Sujitha P } \\
2020^{46}\end{array}$ & EIM & $\begin{array}{l}5 \mathrm{ml} \text { (1 vial) } \\
\times 5 \text { doses }= \\
25 \mathrm{ml}\end{array}$ & $\begin{array}{l}\text { INR } \\
310-351 \sim\end{array}$ & $16.38-18.54 \sim$ & - INR 1750 & 92.46 & $\begin{array}{l}40 \mathrm{IU} / \mathrm{kg} \text { ( } 1 \text { vial } \\
=5 \mathrm{ml} \text { or } 300 \mathrm{IU} \\
\text { Number of vials } \\
=8 \text { ) }\end{array}$ & INR 635 & 33.55 & INR 5080 & 268.39 & $\begin{array}{l}20 \mathrm{IU} / \mathrm{kg}(1 \mathrm{via} \\
=5 \mathrm{ml} \text { or } 300 \\
\mathrm{IU} ; \text { Number of } \\
\text { vials }=4)\end{array}$ & $\begin{array}{l}1 \text { Brand } 1= \\
\text { INR } 5286\end{array}$ & 279.27 & INR 21,144 & 41117.08 \\
\hline
\end{tabular}

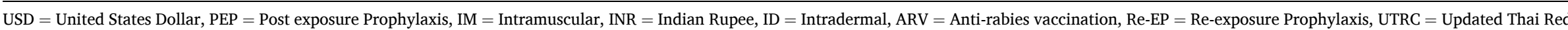
Cross, EIM = Essen Intramuscular, B1 = Brand 1, B2 = Brand 2.

${ }^{\text {a }}$ Cost of procurement of $1 \mathrm{ml}$ vial, \#Government price for $0.5 \mathrm{ml}, \sim$ Price range of 7 different brands, "Maximum Cost per person. 
each category III exposure was USD 10.9 and IDRV for category II exposure was USD 2.08. The cost of PEP with IDRV is significantly lower than PEP with IMRV $(\chi 2=25.76, P<0.005)$.

\subsubsection{Economic costs}

The overall economic costs of canine rabies were estimated to be 2.85 million USD in a modeling study in 2015 . $^{1}$ The economic burden is contributed mainly due to productivity losses from premature deaths (1.96 million USD), direct expenditure on PEP (0.58 million USD) and loss of income while seeking PEP (0.164 million USD). ${ }^{1}$

\subsection{Humanistic burden}

Only one modeling study reported humanistic burden of dog bites or dog-mediated rabies in India. ${ }^{1}$ The study estimated that around 1.3 [0.38-3.4] million DALYs are lost annually in India due to rabies completely due to premature death of rabies victims (Years of life lost). The study also mentioned that no DALYs are lost in India due to adverse events due to the vaccination. However, it did not include the anxiety due to dog bites (in terms of Years lived with disability) in the calculation of DALYs. ${ }^{1}$

\section{Discussion}

Rabies is a fatal disease and programmatic experiences from India are considered to be important to achieve global elimination of dogmediated rabies by 2030 under Global Strategic Plan. There is a need for updated data and studies to estimate burden of rabies in India to take appropriate programmatic decisions to achieve this goal. This systematic review aimed to report the epidemiological, economic and humanistic burden of dog-mediated rabies in India.

Two regional studies reported the crude incidence of dog bites as 26.05 per 10000 in 2012 and 25.0 per 1000 population in 2010-11..$^{40,42}$ One study reported a higher dog bite rate in urban slums in Delhi in comparison to rural slums in 2014, though the finding is not statistically significant. $^{33}$ All the studies reported dog as the main biting animal among all cases of animal bites.

The majority of the dog bite victims were in the age group of 10-40 years. ${ }^{29,31,34,42}$ One study on children below 15 years of age reported that majority of the dog bites are experienced by children in the age group of 7-12 years $(>60 \%){ }^{27}$ Furthermore, the dog bite cases are disproportionately higher in males and in individuals belonging to low socio-economic status. The people working in fields (farmers, labours and unskilled workers) are more vulnerable to dog bites. The majority of the dog bites are single wounds and are suffered in lower extremities (lower limb and buttocks). However, children $(<15$ years of age) are more vulnerable (58\%) to suffer $2-4$ wounds per encounter. ${ }^{27}$ This could be related to their shorter stature and lesser strength to scare away the dogs and may lead to extensive bites requiring operative interventions and thereby resulting in greater morbidity and pain associated with bites and their treatment. ${ }^{53}$ The dogs in the studies mostly bit during day/evening and in pre-monsoon or summer season. None of the study reported dog bites after midnight.

Majority of dogs in reported bites were stray dogs. Though a study reported pet dogs as the main biting animal but $26 \%$ of these pet dogs were reported to be unimmunized stray dogs kept as pet. ${ }^{41}$ Therefore, the immunization of pet dogs along with stray dogs could be an important strategy to break the chain of rabies transmission.

Two studies reported dog as the main animal responsible for rabies deaths in India. ${ }^{4,26}$ The incidence of rabies is disproportionately high in males and individuals below 30 years of age.

The systematic review reported a gradual decrease in the cost of one vial of vaccine and the cost of vaccination has been reported lower in ID regimens. There is a significant difference between the cost of one vial of ERIG and HRIG. The inflated cost of $5 \mathrm{ml}$ of ERIG was reported to be USD 29.23 and USD 33.55 in study conducted in 2013 and 2020 respectively ${ }^{44,46}$ and the inflated cost of $2 \mathrm{ml}$ of HRIG for two different brands in 2013 was USD 186.5 and USD 434.15. A $5 \mathrm{ml}$ vial of HRIG cost USD 279.27 in a study conducted in $2020 .{ }^{46}$ Furthermore, there is a huge difference in the maximum cost of ERIG and HRIG administration in the category III exposures. The maximum cost of required ERIG (calculated as per body weights) was USD 54 in 2013 and USD 268.39 in 2020 but the maximum cost of required HRIG is as high as USD 1117.08 in a study conducted in $2020 .{ }^{46}$ The ID treatment regimens are less costly than IM regimens due to fewer doses of ID vaccines and lesser utilization of vaccines. The cost of providing ID ARV with ERIG in category III exposures has been reported to be USD 10.9 and USD $11^{44,47}$ while the cost of providing IMRV with ERIG was reported to be USD 19.7 and USD $360.84 .{ }^{46,50}$ The cost of IMRV with HRIG was reported as high as USD 1209.53. ${ }^{46}$ Therefore, the combination of ID ARVs with ERIG is a less costly approach as PEP than combination of IM ARVs with ERIG or ARVs with HRIG.

The review also reported a significant reduction (80\%) in the dose of ERIG in the strategy of local infilteration in wounds without systemic IM administration with similar rates of survival. Therefore, local wound infilteration only of ERIG can be an effective and cost saving strategy. ${ }^{51,52}$

\subsection{Evidence gaps}

There is a dearth in the availability of quality literature in the country on dog bites and dog-mediated rabies and most of the studies are regional studies, based on records and secondary data analysis from hospital/clinic settings on animal bites without differentiation in to dog bites. The studies reporting estimates at national level are mostly derived from modelling study and not on primary data analysis. Substantial gaps in the present study need to be addressed to determine the prevalence and incidence, humanistic burden on patients and their care givers, and the economic burden associated with dog-mediated rabies in India. In particular, we did not identify any information on prevalence/ incidence estimates of dog bites through national data in last 5 years. Additionally, we did not identify any articles in the last decade that had reported primary data on the incidence of dog-mediated rabies, trends in incidence or prevalence of dog-mediated rabies over time, costs associated with the use of monoclonal antibodies and cost of illness associated with dog-mediated rabies in India.

\section{Conclusion}

This systematic review attempted to estimate the epidemiological, humanistic and economic burden of dog-bites and dog-mediated rabies in India. It has highlighted the burden of disease at local, regional and national level as reported in various primary studies, secondary data analysis and modeling studies. Understanding the burden of dog bites and rabies in the country will help policymakers in effective decision making, proper allocation of scarce resources and funding and; thereby, formulation and implementation of best suited interventions at programmatic level. The findings will also be helpful in implementation research and modeling studies. The review also identified key evidence gaps in the existing scientific literature. There has been dearth of studies reporting economic and humanistic burden of the disease through primary data. This is also helpful for researchers to identify potential areas of research in context of dog bites and rabies in India.

\section{CRediT authorship contribution statement}

Denny John: Conceptualization, Investigation, Methodology, Project administration, Resources, Supervision, Validation, Writing - review \& editing. Abhishek Royal: Data curation, Formal analysis, Investigation, Validation, Writing - original draft, Preparation, Writing - review \& editing. Omesh Bharti: Conceptualization, Investigation, Project administration, Supervision, Validation, Writing - review \& editing. 


\section{Acknowledgement}

We acknowledge the help of Mrs Vasumathi Sriganesh, Founder, QMed Knowledge Foundation for her guidance in the development of Search Strategy for this systematic review.

\section{Appendix A. Supplementary data}

Supplementary data to this article can be found online at https://doi. org/10.1016/j.cegh.2021.100804.

\section{References}

1 Hampson K, Coudeville L, Lembo T, et al. Estimating the global burden of endemic canine rabies, 4. In: Carvalho MS, ed. PloS Negl Trop Dis [Internet]. vol. 9. 2015 Ap 16, e0003709. Available from: https://dx.plos.org/10.1371/journal.pntd.0003709. Accessed December 28, 2020.

2 Rabies vaccines and immunoglobulins: WHO position [Internet]. [cited 2020 Dec 28]. Available from: https://www.who.int/immunization/policy/position_papers/ pp_rabies_summary_2018.pdf; April 2018.

3 WHO expert consultation on rabies third report [internet] [cited 2020 Dec 28]. Available from: https://apps.who.int/iris/bitstream/handle/10665/272364/978 9241210218-eng.pdf? sequence $=1$ \&isAllowed=y; 2018.

4 Suraweera W, Morris SK, Kumar R, Warrell DA, Warrell MJ, Jha P. Deaths from symptomatically identifiable furious rabies in India: a nationally representative mortality survey. In: Zinsstag J, ed. PloS Negl Trop Dis [Internet]; 2012 Oct 4 [cited 2020 Dec 28];6(10):e1847. Available from: https://dx.plos.org/10.1371/journal. pntd.0001847.

5 Fooks AR, Banyard AC, Horton DL, Johnson N, McElhinney LM, Jackson AC. Current status of rabies and prospects for elimination [Internet]. Lancet. Lancet Publ Group. 2014;384 [cited 2020 Dec 28]. P. 1389-99. Available from: https://www.thelancet. com/journals/lancet/article/PIIS0140-6736(13)62707-5/fulltext.

6 Director General Of Health Services G of I. National rabies control Programme (zoonosis division) [Internet] 2014;1. [cited 2020 Dec 28] Available from: http://dghs.gov.in/WriteReadData/userfiles/file/National Rabies Control Prog ramme.pdf.

7 Second draft ministry of health and family welfare 2 draft national action plan for eliminating dog mediated rabies from India [Internet]. [cited 2020 Dec 28] Available from: https://www.ncdc.gov.in/WriteReadData/1892s/25879243771600146411. pdf.

8 ZERO BY 30 the Global Strategic Plan to end human deaths from dog-mediated rabies by 2030 [Internet] [cited $2020 \mathrm{Dec} 28$ ]. Available from: https://apps.who.int/iris /bitstream/handle/10665/272756/9789241513838-eng.pdf?ua=1.

9 Kole AK, Roy R, Kole DC. Human rabies in India: a problem needing more attention [Internet]. Bull World Health Org World Health Org. 2014;92 [cited 2020 Dec 28]. P. 230. Available from: https://www.ncbi.nlm.nih.gov/pmc/articles/PMC3967582/.

10 Sudarshan MK, Ashwath Narayana DH. Background paper for developing a policy for the use of rabies biologicals and vaccination of humans in India. Indian $J$ Public Health [Internet]. 2019;63(5):51-53, 63(5):S51-3. Available from: https://www.ijph. in/article.asp?issn=0019-557X.

11 Page MJ, McKenzie JE, Bossuyt PM, et al. The PRISMA 2020 statement: an updated guideline for reporting systematic reviews. BMJ. 2021;372:n71. https://doi.org/ 10.1136/bmj.n71.

12 John D, Royal A, Bharti O. Epidemiological, humanistic and economic burden of dogmediated rabies in India: a systematic review protocol [version 2; peer review: 2 approved]. F1000Research. 2021;10:32. https://doi.org/10.12688/ f1000research.28454.1. Available from:

13 Ouzzani M, Hammady H, Fedorowicz Z, Elmagarmid A. Rayyan-a web and mobile app for systematic reviews. Syst Rev [Internet] [cited 2020 Dec 28];5(1). Available from: https://link.springer.com/epdf/10.1186/s13643-016-0384-4; 2016 Dec 5.

14 CCEMG. EPPI-centre cost converter v.1.4 [internet] [cited 2020 Sep 29]. Available from: https://eppi.ioe.ac.uk/costconversion/.

15 STROBE Statement-Checklist of items that should be included in reports of cohort studies [Internet] [cited 2020 Dec 10]. Available from: https://www.strobe-statem ent.org/fileadmin/Strobe/uploads/checklists/STROBE_checklist_v4_cohort.pdf.

16 STROBE Statement-Checklist of items that should be included in reports of casecontrol studies [Internet] [cited 2020 Dec 10]. Available from: https://www.strobestatement.org/fileadmin/Strobe/uploads/checklists/STROBE_checklist_v4_cross-sect ional.pdf.

17 CHEC list: Consensus health economic criteria - research - maastricht university [internet] [cited $2020 \mathrm{Dec} 10]$. Available from: https://www.maastrichtuniversity.n /research/caphri/our-research/creating-value-based-health-care/chec-list-consensu s-health-economic.

18 Husereau D, Drummond M, Petrou S, et al. Consolidated health economic evaluation reporting Standards (CHEERS) statement. BMJ. 2013;346:f1049. https://www.bmj. com/content/346/bmi.f1049.

19 Kopec JA, Finès P, Manuel DG. Validation of population-based disease simulation models: a review of concepts and methods. BMC Public Health. 2010;10:710. https:// doi.org/10.1186/1471-2458-10-710.

20 Teena MJ, Mathew T, Anish TS, Sujina CM, Philip RR. Post-exposure prophylaxis against rabies at two newly designated intradermal rabies vaccination clinics in Kerala, India. Natl Med J India. 2012;25(5):268-270.
21 Shah V, Bala DV, Thakker J, et al. Epidemiological determinants of animal bite cases attending the anti- rabies clinic at V S General Hospital. Ahmedabad. Healthline [Internet]. 2012;3(1):66-68. http://www.iapsmgc.org/index_pdf/17.pdf.

22 Chauhan P, Saini G. Studyof profile of animal bite victims attending anti-rabies clinic at Jodhpur in 2012. J Med Sci Public Health. 2013:2:1088-1091.

23 Venkatesan M, Dongre AR, Kalaiselvan G. An epidemiological study of animal bites and envenomings in a rural district of Tamilnadu, India. Online J Health Allied Sci. 2014;13(4):6.

24 Acharya R, Sethia R, Sharma G, Meena R. An analysis of animal bite cases attending anti-rabies clinic attached to tertiary care centre, Bikaner, Rajasthan, India. Int J Commun Med Public Heal. 2016;3(7):1945-1948.

25 Marathe N, Kumar S. Epidemiological study of animal bite victims in Central India: a cross sectional institutional study. Int J Commun Med Public Heal. 2016;3(1):78-82.

26 Sudarshan MK, Ashwath Narayana DH. Appraisal of surveillance of human rabies and animal bites in seven states of India. Indian J Public Health [Internet]. 2019 Sep 1; 63(5):3. year $=2019$; volume $=63$;issue $=5$; spage $=3$;epage $=8$; aulast $=$ Sudarshan htt p://www.ijph.in/article.asp?issn=0019-557X. Accessed July 5, 2020.

27 Hemagiri K, Someshwar GM, Karinagannanavar A. An epidemiological study on dog bite and its management in Bellary, Karnataka. J Commun Dis. 2012;44(1):15-23.

28 Wankhede V, Waingankar P, Anjenaya S, Telang BT. Epidemiological study of dog bite cases reported at ARV clinic of rural hospital panvel in raigad district of Maharashtra. India. 2013;8(1):52-55.

29 Bharathy S, Gunaseelan L. A cross sectional study to understanding demographics of dog bite victims attending anti rabies ward in Chennai City, Tamil Nadu India. Adv Anim Vet Sci. 2017;5(2):78-82.

30 Sharma N, Meena G, Rathore M, Verma M, Raj D, Yadav R. Problem Causes Considerable Phys. 2019;7(8):117-120.

31 Thahaby N, Akand AH, Hamdani SA, et al. Epidemiological pattern of dog bites and the occurrence of rabies in humans within Srinagar district of Kashmir Valley, India. Comp Immunol Microbiol Infect Dis [Internet]. 2020;73(October):101556. https://doi. org/10.1016/j.cimid.2020.101556.

32 Agarwal N, Reddajah VP. Epidemiology of dog bites: a community-based study in India. Trop Doct. 2004;34(2):76-78.

33 Sharma S, Agarwal A, Khan A, Ingle G. Prevalence of dog bites in rural and urban slums of Delhi: a community-based study. Ann Med Health Sci Res. 2016;6(2):115.

34 Ghosh A, Pal R. Profile of dog bite cases in an urban area of Kolkata, India. Natl $J$ Community Med. 2014;5(3):321-324.

35 Singh T, Mahajan S, Dahiya N. A cross sectional study of awareness and practices regarding animal bites in rural community, North India. J Fam Med Prim Care. 2020; 9:2751-2757.

36 Mani RS, Anand AM, Madhusudana SN. Human rabies in India: an audit from a rabies diagnostic laboratory. Trop Med Int Health. 2016;21(4):556-563.

37 Sudarshan MK, Madhusudana SN, Mahendra BJ, et al. Assessing the burden of human rabies in India: results of a national multi-center epidemiological survey. Int $\mathrm{J}$ Infect Dis;11(1):29-35. http://intl.elsevierhealth.com/journals/ijid.

38 Sangeetha S, Shakthi SHMV, Sarala MD, et al. An epidemiological study of dog bite cases in a rural area of Salem. Tamil Nadu. Public Health Rev Int J Public Health Res. 2018;5(2):99-104. https://publichealth.medresearch.in/index.php/ijphr/article/vie w/89.

39 Vernekar SP, Desai A. A study of dog bites among children in the rural area of Goa, India. J Prev Med Holist Health. 2018;4(1):20-23. https://doi.org/10.18231/24546712.2018.0006.

40 Masthi NRR, Sudarshan MK. Understanding dynamics of animal bites and rabies prophylaxis in a rural community - an explorative study. APCRI J. 2015;XVI(II): 9-11.

41 Bharti OK, Thakur B, Rao R. Wound-only injection of rabies immunoglobulin (RIG) saves lives and costs less than a dollar per patient by "pooling strategy. Vaccine [Internet]. 2019;37(August):A128-A131. https://doi.org/10.1016/j. vaccine.2019.07.087.

42 Khan V, Zala DB, Joshi KM, Das VK. A study on dog bite incidence in union territory of dadra \& nagar Haveli, India. J Appl Nat Sci. 2014;6(1):38-40.

43 Knobel DL, Cleaveland S, Coleman PG, et al. Re-evaluating the burden of rabies in Africa and Asia. Bull World Health Organ. 2005 May;83(5):360-368.

44 M V S, Culas R. Cost analysis of post exposure prophylaxis of rabies in A tertiary care centre- A cross sectional study. IOSR J Dent Med Sci. 2014;13(12):8-12.

45 Kundu BK, Meshram GG, Bhargava S, Meena O. Cost savings of using updated Thai red cross intradermal regimen in a high-throughput anti-rabies clinic in New Delhi, India. Trav Med Infect Dis. 2019;4(1).

46 Sujitha P, Swetha NB, Gopalakrishnan S. Cost analysis of rabies prophylaxis in India. Int J Commun Med Public Heal. 2020;7(9):3403.

47 Abbas SS, Kakkar M, Rogawski ET. Costs analysis of a population level rabies control Programme in Tamil Nadu, India. PLoS Neglected Trop Dis. 2014;8(2).

48 Goswami A, Plun-Favreau J, Nicoloyannis N, Sampath G, Siddiqui MN, Zinsou JA. The real cost of rabies post-exposure treatments. Vaccine. 2005;23(23):2970-2976.

49 Jyoti Goel MK, Vashisht BM, Khanna P. Pattern and burden of animal bite cases in a tertiary care hospital in Haryana. J Commun Dis. 2010;42(3):215-218.

50 Haradanhalli RS, D Hanumanthaiah AN, Varadappa ST. Cost of rabies post exposure prophylaxis in different healthcare settings in six states of India. Indian J Publ Health. 2019;63:S44-S47.

51 Bharti OK, Madhusudana SN, Gaunta PL, Belludi AY. Local infiltration of rabies immunoglobulins without systemic intramuscular administration: an alternative cost effective approach for passive immunization against rabies. Hum Vaccines 
Immunother [Internet]. 2016;12(3):837-842. https://doi.org/10.1080/

21645515.2015 .1085142$.

52 Bharti OK, Madhusudana SN, Wilde H. Injecting rabies immunoglobulin (RIG) into wounds only: a significant saving of lives and costly RIG. Hum Vaccines Immunother [Internet]. 2017;13(4):762-765. https://doi.org/10.1080/21645515.2016.1255834.
53 Venkatesh KL, Bhaskar A, Vepakkomma D. Study of morbidity of pediatric dog bites: single center experience. Int Surg J. 2017;4:185-188. 